\title{
Family Support for the Independence of Children with Special Needs for Self-Care: Literature Review
}

\author{
${ }^{1 *}$ Ita Pursitasari, ${ }^{2}$ Allenidekania \\ ${ }^{1}$ Bandung Health Polytechnic Bogor Nursing Study Program, Bogor, Indonesia \\ ${ }^{2}$ Faculty of Nursing, Universitas Indonesia, Depok, Indonesia
}

\begin{abstract}
Children with Special Needs are children who have long-term problems on the physical or mental causes a child unable to carry out daily activities and interact with other people in the community (Cavallo, 2009). The limitations experienced by Them cause problems in self-care which result in health problems. So They can live quality, especially in terms of self-care needed support from his family. The goal is to find out family support for the independence of children with special needs in carrying out self-care. The method used is literature by taking some of the results of previous research from several scientific articles in the journal. The results of the literature review show that there is a need for parental support to establish children with special needs in carrying out self-care
\end{abstract}

Keywords: Children With Special Needs, Self care, Family support

\section{Background}

Children with Special Needs are children with mental retardation, hearing loss (deafness), speech and language disorders, visual impairments (blind), serious emotional disorders, orthopedic disorders, autism, traumatic brain injury, certain learning disabilities and those who need special education and service related (Bowden, 2010). According to (Cavallo, Feldman, Swaine, \& Meshefedjian, 2009) Children with Special Needs have long-term physical or mental problems that cause a child to be unable to carry out daily activities and interact with other people in the community. WHO in 2003 estimated the number of children with special needs in Indonesia to be around 295,250 children.

Children with special needs has problems or obstacles in health and various circumstances. Hockenberry and Wilson (2009) categorize children with special needs in 6 major categories, namely: children with chronic diseases, children with terminal diseases,

* Corresponding author: Ita Puspitasari, Allendekania ithapur@gmail.com

Published online at http://IJDS.ub.ac.id/

Copyright @ 2019 PSLD UB Publishing. All Rights Reserved that is children who were considered medically unable to return their conditions or the possibility of death from certain diseases is very large, children with anomalies congenital, children with physical disabilities (paralysis, blind, deaf, and others), children with multiple / multiple disabilities that is the children who have disabilities more than one type, children with cognitive and developmental disorders (down syndrome, autism, mental retardation, and so forth).

Problems are often found in $\mathrm{ABK}$, namely lack of social interaction in community and school activities, limited activities, developmental delays, and behavioral and emotional problems (Hockenberry, 2009 and Cavallo, 2009). Other problems that arise are intellectual limitations, limitations of limbs (Smits et al., 2011; Tan et al., 2014).

According to Demographics, Rehabilitation Research and Training Center on Disability Statistics (2016), the ability to self-care independently in individuals with disabilities is around $15.6 \%$, while according to the American Community Survey (ACS) states that the prevalence of self-care ability in individuals aged 5 to 17 who experience disabilities is as much as $0.9 \%$. 
Parental support is needed in overcoming the impact of ABK's inability to carry out selfcare. According to research by Rinald \& Mirenda (2012), parents are taught how to train toileting in children by setting a schedule for toilet toilets, increasing fluid intake, positive reinforcement for elimination in the toilet, guidance for teaching self initiation, and punishment for failing to do toileting, from all of these steps are obtained that all children are able to use toilets in other places such as your home, school and public places.

The purpose of this paper is to identify family support for the independence of children with needs in self-care.

\section{Method}

\subsection{Data search}

Data search was carried out in accordance with the PRISMA guidelines. Searched data included Taylor \& Francis, Clinical Key, Sage Journals, Elsevier Science Direct, Scopus LateraL, Wiley on Line Library. Searches that involve reviewing reference lists in papers are also conducted.

The search uses the term children with special needs, disabilities, family support, family support, personal hygiene and disability for children, fcc disability of children, family support and disability of children, self care in disability of children, mother, father, family, disability kids, children with special needs, family roles, family support and children with special needs. There is no limit in terms of the date of publication or the requirements for the text are only written in English.

\subsection{Inclusion Criteria}

Initially, 326 articles were identified, then became 304 articles after the duplicates were deleted. The first selection was done by the author by filtering the title and abstract by referring to "family support / support of parents and children with special needs / disability child / disability kids" and children under the age of 18 years.

\subsection{Extraction Data}

Data is released if not children with special needs, the sample is children with special needs with age above 18 years, not in English, parents not with children with special needs, families not with children with special needs, family support not in children with special needs, which resulted in 75 articles which were carried out by reading abstracts to see conformity. Then from 75 papers read and produce 30 appropriate articles. There is no limit on study design, either longitudinal or cross sectional studies. The articles meet the selection criteria if they specifically discuss self-care, personal hygiene, and then be associated with family support. There is no limit to the type of disability. The author extracts information independently by using tables. Nonconformity is done by re-reading the article. Nine of the 30 articles met the selection criteria and were included in this review.

\section{Results}

Nine articles about parental support with self-care abilities in children with special needs were included in this study. Table 1 summarizes information relating to the author, article title, year of publication, journal name, method, and results of the article. From 9 studies, 7 used quantitative methods, 1 used qualitative methods and 1 study used combined quantitative and qualitative methods. From 9 studies 5 studies used a sample of children while the rest used a sample of parents with children with special needs. For the research method 1 the study used pre-experimental, 1 study used quasi experiment and 2 studies used a longitudinal method of study cohort.

\subsection{Self care}

Self-care is an activity such as drinking, eating, personal hygiene (Zarchi., Et al, 2018). Self-care in the literature review here includes toilet toileting and urination, dental hygiene and genital hygiene. According to Paulks, et al. (2013) $42.6 \%$ of children with special needs experienced dental caries, $44 \%$ experienced dentofacial anomaly, $58 \%$ had a tooth structure disorder and $9.2 \%$ had caries and dentofacial anomaly. While the research conducted by Zacharin, Savasi, \& Grover, (2010) in women with disabilities in children aged 12-18 years, there were 59 people $(76 \%)$ who felt happy to get their first period, $50 \%$ asked for advice before getting their first menstruation and the 
severity of disability strongly associated with the state of the child during menstruation In addition to cleaning the genitalia in boys with intellectual disability is not consistent (Wilson., et al, 2009).

\subsection{Family support}

Parental support is very much needed to make the children with special needs independent in self-care. According to Teles, Resegue, \& Puccini, (2016), children with special needs in performing social functions need more assistance from caregivers and need support and guidance to overcome existing problems. Practicing self-care for children with physical disabilities can improve their abilities, attitudes and skills, but do not affect their knowledge (Ningsih, Purwanto and Hartati, 2018). According to Cohen, Holloway, DominguezPareto, \& Kuppermann (2014), the quality of life of children with special needs is better, namely those who get care by mothers with higher education and get social support from all family members

\section{Discussion}

Some crews experience problems in intellectual matters, (Tan et al., 2014) mentioning that the level of non-verbal intellectual development is influenced by the severity of Cerebral palsy. Nonverbal intellectual capacity in children with mild Cerebral palsy shows an intellectual level similar to its development, while severe cerebral palsy children exhibit limited intellectual development compared to its development. In addition, another problem that can be found in children with special needs is the limitation of limbs, such as research conducted by (Tan, et al., 2014; Colver, et al., 2014) which states that children with cerebral palsy face challenges in daily life, where they experience problems with flexibility, contractures, dyskinesia, and sensory damage so that they can interfere with daily activities such as dressing, writing, etc.

As a result of their limitations, children with special needs often experience health problems. According to Mazecaite-Vaitilaviciene \& Owens, (2018) with the retrospective method it was stated that dental health in children with special needs in Lithuania was very poor, where $72 \%$ of children with special needs had 5 teeth damaged and as many as $27 \%$ of children with special needshas 10 damaged teeth. Another study conducted by Limeres et al (2013), on 60 children with disabilities in Spain stated that brushing teeth twice a day as many as 19 people $(31.7 \%)$ three times a day as many as 18 people $(30 \%)$ and sometimes as many as 10 people $(16.7 \%)$. Other health problems found in children with special needs are dental health, where as many as $42.6 \%$ of dental caries $44 \%$ dentofacial anomaly, $58 \%$ of tooth structure disorders $9.2 \%$ experience caries and dentofacial (Faulks et al., 2013).

Caring for children with special needs is not easy, it takes a lot of time, patience and love. Parents and family members are the main care providers in the community, so they need a lot of support from the community to care for children with children with special needs (Yadwinder, k.2010). Parenting style is not only influenced by stress, but also influenced by family functions. For example, in a family having normal children and children with children with special needs, family functions affect parenting styles differently (Cohen et al., 2014)

Parental support is needed to make children with special needs independent in doing personal hygiene. Mundenke, Hermanssoon \& Natterlund (2010) states that social support is needed by children with special needs, one of which is research conducted on children with intellectual impairments requiring instrumental support from their parents, for example in carrying out self-care, in addition to their parents receiving instrumental support from you biological or other close relatives. In addition to self-care, another problem that is found is experiencing difficulties about the concept of time when an activity is done in a different time, for example children with special needs requires informative support from parents where they should be in the afternoon and what to do after school. Family support provided is very helpful in minimizing psychological complaints, providing strength, motivation and energy and reducing uncertainty and insecurity that will affect the health and quality of life of children with special needs (Brolind and Osberg, 2006). 


\section{Limitations}

In the literature search there are obstacles where it is difficult to find articles related to family support and personal hygiene, or family support for children with special needs

\section{Conclusion}

Children with special needs has limitations, both in terms of intellectual abilities or activities. Due to its limitations children with special needs has problems in self-care fulfillment independently, so often children with special needs have health problems due to lack of self-care. The role and support of the family is very necessary to help children with special needs in fulfilling their daily needs so that children are more qualified in life.

\section{References}

Berbiglia, V. A. (2011). The Self Care Deficit Nursing Theory as a Curriculum Conceptual Framework in Baccalaureate Education. Journals of Nursing Science 24(2) 137-145 (1). https://doi.org/10.1177/0894318411399452

Bowden, V.R. (2010). Children and their families: The continuum of care (2nd ed.). Philadelphia: Lippincott Williams \& Wilkins.

Brolin Laftman S, Ostberg V. (2006) The pros and cons of social relations: An analysis of adolescents' health complaints. Soc Sci Med. 2006;/63:/611 23

Cavallo, S., Feldman, D. E., Swaine, B., \& Meshefedjian, G. (2009). Is parental coping associated with the level of function in children with physical disabilities? Child: Care, Health and Development, 35(1), 33-40. https://doi.org/10.1111/j.1365-

2214.2008.00884.x

Cohen, S. R., Holloway, S. D., DomínguezPareto, I., \& Kuppermann, M. (2014). Receiving or believing in family support? Contributors to the life quality of Latino and non-Latino families of children with intellectual disability. Journal of Intellectual Disability Research. 58(4), 333-345. https://doi.org/10.1111/jir.12016

Cervadio, Kathleen. (2013). Attitudes of Nurses Toward Children With Disabilities: The
Attitudes of Nursing Students Toward Children With Disabilities: An Experimental Design. International Journal of Physical Medicine \& Rehabilitation $01 \quad$ (05): $1-15$. https://doi.org/10.4172/2329-9096.1000140.

Cameron, Debra, Tammy Craig, Brydne Edwards, Cheryl Missiuna, Heidi Schwellnus, and Helene J. Polatajko. (2017). Cognitive Orientation to Daily Occupational Performance (CO-OP): A New Approach for Children with Cerebral Palsy. Physical and Occupational Therapy in Pediatrics 37 (2): 183-98. https://doi.org/10.1080/01942638.2016.118550 0 .

Demographics, Rehabilitation Research and Training Center on Disability Statistics and. (2016). 2016 Disability Statistics Annual Report.

https://disabilitycompendium.org/sites/default/fi les/user uploads/2016_AnnualReport.pdf.

Faulks, D., Norderyd, J., Molina, G., Macgiolla Phadraig, C., Scagnet, G., Eschevins, C., \& Hennequin, M. (2013). Using the International Classification of Functioning, Disability and Health (ICF) to Describe Children Referred to Special Care or Paediatric Dental Services. PLoS ONE. 8(4). https://doi.org/10.1371/journal.pone.0061993

Francis, Mannion \& Leader. (2017). The Assessment and Treatment of Toileting Difficulties in Individuals with Autism Spectrum Disorder and Other Developmental Disabilities. Rev J Autism Dev Disord (2017) 4:190-204 DOI 10.1007/s40489-017-0107-3

Hockenberry, M.J. \& Wilson, D. (2009). Wong's Essentials of pediatric nursing. (8th ed.). St. Louis: Mosby Elsevier.

Jukes.(2011). Challenges affecting the learning disability nursing role: past and present. Learning disability practice. Volume 14 .No 10

Limeres., et al. (2013). A new indicator of the oral hygiene habits of disabled persons: relevance of the carer's personal appearance and interest in oral health. International Journal of Dental Hygiene. DOI: 10.1111/idh.12033 
Liss, M., Harel, B., Fein, D., Allen, D., Dunn, M., Feinstein, C., ... \& Rapin, I. (2001). Predictors and correlates of adaptive functioning in children with developmental disorders. Journal of Autism and Developmental Disorders, 31, 219-230.

Mundhenke, Hermansson, \& Natterlund. (2010). Experiences of Swedish children with disabilities: activities and social support in daily life. Scandinavian journal of occupational Therapy. ISSN 1103-8128 print/ISSN 16512014 online \# 2010 Informa UK Ltd. (Informa Healthcare, Taylor \& Francis AS) DOI: $10.3109 / 11038120903114386$

Ningsih, Warti, Purwanta Purwanta, and Sri Hartini .(2018). Self-Care Training Improves the Attitudes and Skills of Caregivers for Children with Physical Disability. Jurnal Ners. 13 (1): 9-17.

Phadraig.,et al.(2014). What Should Dental Services for People with Disabilities Be Like? Results of an Irish Delphi Panel Survey. PLoS ONE 9(11): e113393. doi:10.1371/ journal

Rinald, K., \& Mirenda, P. (2012). Effectiveness of a modified rapid toilet training workshop for parents of children with developmental disabilities. Research in Developmental Disabilities, 33(3), 933-943. https://doi.org/10.1016/j.ridd.2012.01.003

Smits.,et al,(2011). Development of non-verbal intellectual capacity in school-age children with cerebral palsy. Journal of Intellectual Disability Research. volume 55 part 6 pp 550-562 june 2011. doi: 10.1111/j.1365-2788.2011.01409.x

Shepherd,Landon \& Goedekc. (2017). Symptom severity, caregiver stress and intervention helpfulness assessed using ratings from parents caring for a child with autism. The Author(s) 2017 Reprints and permissions: sagepub.co.uk/journalsPermissions.nav DOI: 10.1177/1362361316688869

Sparrow, S. S., Cicchetti, D. V., \& Balla, D. A. (2005). Vineland adaptive behavior scales (2nd ed.). Circle Pines: AGS Publishing

Tan.,et al. (2014). Long-Term Trajectories of Health-Related Quality of Life in Individuals with Cerebral Palsy: A Multucenter Longitudinal Study. Archieves of Physical
Medicine and Rehabilitation. 95: 2029-39 http;//dx.doi.org/10.1016/j.apmr.2014.04.031

Teles, Fernanda Moreira, Rosa Resegue, and Rosana Fiorini Puccini. (2016). REVISTA PAULISTA Care Needs of Children with Disabilities - - Use of the Pediatric Evaluation of Disability Inventory. Revista Paulista de Pediatria (English Edition) 34 (4): 447-53. https://doi.org/10.1016/j.rppede.2016.02.015

Vaitilavicience.M.L.\& Owens.j. (2018). Children with disabilities at risk of poor oral health in the republic of Lithuania: A Retrospective descriptive service evaluation. World medical and health policy.doi: 10.1002/wmh3.275.

Wilson, N. J., Cumella, S., Parmenter, T. R., Stancliffe, R. J., \& Shuttleworth, R. P. (2009). Penile hygiene: Puberty, paraphimosis and personal care for men and boys with an intellectual disability. Journal of Intellectual Disability Research, 53(2), 106-114. https://doi.org/10.1111/j.1365-

2788.2008.01133.x

Yadwinder, Kaur, and Yadwinder Kaur. (2017). Family Support Model for the Management of Disabled Children Family Support Model for the Management of Disabled Children. Studies and Home Community Science Sci, 4(3): 179184 7189 . https://doi.org/10.1080/09737189.2010.118853 20.

Zacharin, Margaret, Ingrid Savasi, and Sonia Grover. (2010). The Impact of Menstruation in Adolescents with Disabilities Related to Cerebral Palsy. Archives of Disease in Childhood $95 \quad$ (7): $526-30$. https://doi.org/10.1136/adc.2009.174680

Zarchi, M S, S M M Fatemi Bushehri, and M Dehghanizadeh. (2018). SCADI: A standard dataset for self-care problems classification of children with physical and motor disability.International Journal of Medical Informatics.

https://doi.org/10.1016/j.ijmedinf.2018.03.003. 

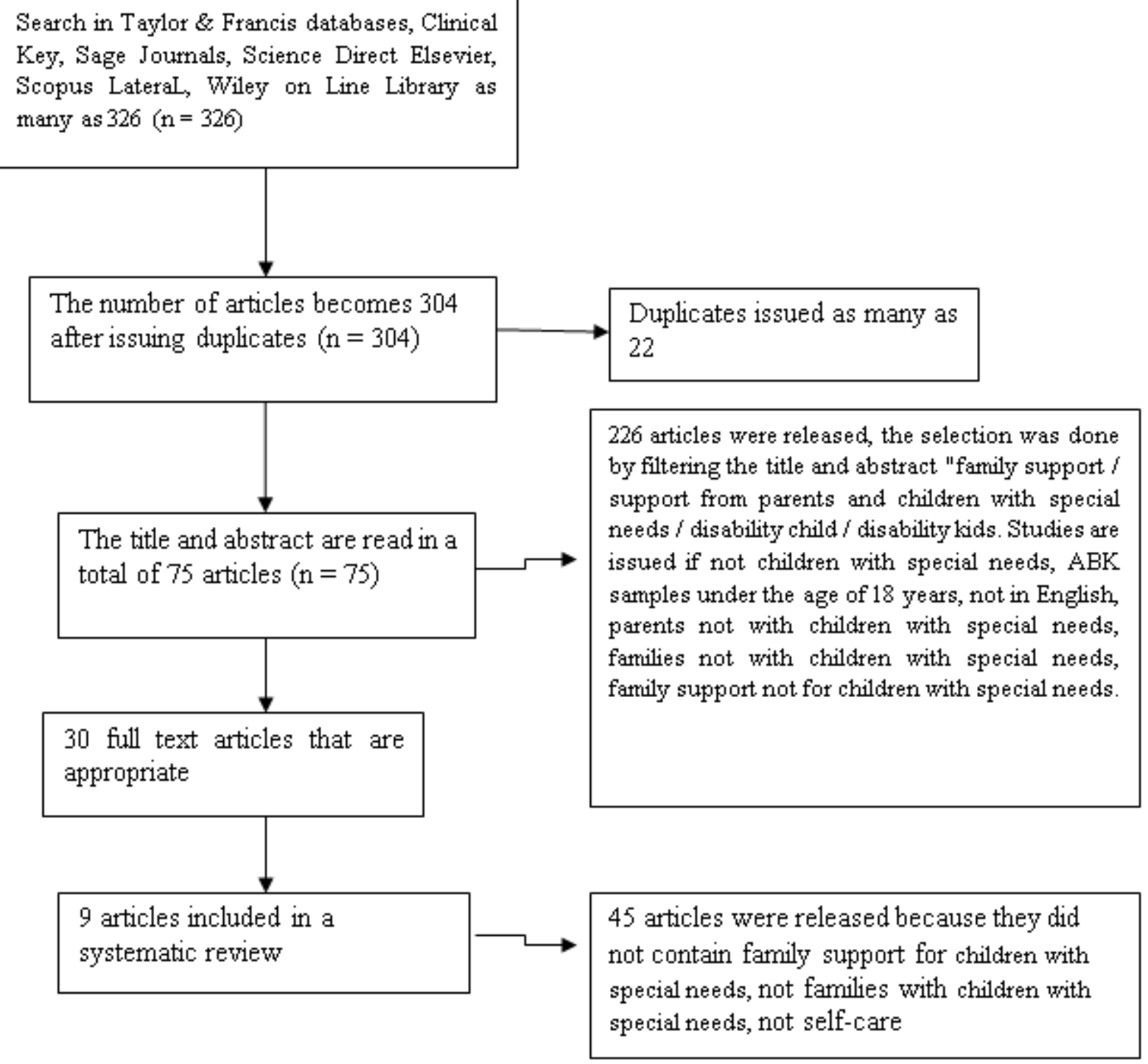

Figure 1. Search strategy 
Table 1 Results of literature review

\begin{tabular}{|c|c|c|c|c|c|c|c|}
\hline No & Author Name & $\begin{array}{c}\text { Article } \\
\text { Title }\end{array}$ & $\begin{array}{c}\text { Year } \\
\text { Published }\end{array}$ & $\begin{array}{c}\text { Journal } \\
\text { Name }\end{array}$ & $\begin{array}{c}\text { Subject } \\
\text { Research }\end{array}$ & $\begin{array}{c}\text { Research } \\
\text { Method }\end{array}$ & Result \\
\hline 1 & $\begin{array}{l}\text { Ningsih, purwanto, } \\
\text { hartati }\end{array}$ & $\begin{array}{l}\text { Self-Care } \\
\text { Training } \\
\text { Improves the } \\
\text { Attitudes and } \\
\text { Skills of } \\
\text { Caregivers for } \\
\text { Children with } \\
\text { Physical } \\
\text { Disability }\end{array}$ & 2018 & $\begin{array}{l}\text { Journal of } \\
\text { Ners }\end{array}$ & $\begin{array}{l}\text { Caregiver in } \\
\text { children with } \\
\text { physical } \\
\text { disabilities }\end{array}$ & $\begin{array}{l}\text { Pre } \\
\text { experimental } \\
\text { with a one } \\
\text { group pre- } \\
\text { test-post-test } \\
\text { design } \\
\text { without } \\
\text { control } \\
\text { group }\end{array}$ & $\begin{array}{l}\text { Nearly half of the knowledge prior to self-care training was } \\
\text { good and, after training, the majority became good. More } \\
\text { than half of the caregivers' attitudes have positive results } \\
\text { before training and this increases almost all after training. } \\
\text { Self-care training for caregivers of children with physical } \\
\text { disabilities can improve their abilities, attitudes and skills, } \\
\text { but do not affect their knowledge. }\end{array}$ \\
\hline 2 & $\begin{array}{ll}\text { Teles, } \\
\text { Pucinni }\end{array}$ & $\begin{array}{l}\text { Care needs of } \\
\text { children with } \\
\text { disabilities } \\
\text { Use of the } \\
\text { Pediatric } \\
\text { Evaluation of } \\
\text { Disability } \\
\text { Inventory }\end{array}$ & 2016 & Pediatria & $\begin{array}{l}\text { Children with } \\
\text { physical or } \\
\text { mental } \\
\text { disabilities } \\
\text { aged } \quad 7-10 \\
\text { years }\end{array}$ & $\begin{array}{l}\text { Cross } \\
\text { sectional }\end{array}$ & $\begin{array}{l}\text { Social functions require more assistance from caregivers } \\
\text { and need support and guidance to overcome problems }\end{array}$ \\
\hline 3 & Rinald \& Mirenda & $\begin{array}{l}\text { Effectiveness } \\
\text { of a modified } \\
\text { rapid toilet } \\
\text { training } \\
\text { workshop for } \\
\text { parents of } \\
\text { children with } \\
\text { developmental } \\
\text { disabilities }\end{array}$ & 2013 & elsevier & $\begin{array}{l}\text { Children with } \\
\text { developmental } \\
\text { disorders }\end{array}$ & $\begin{array}{l}\text { Quasi } \\
\text { experiment }\end{array}$ & $\begin{array}{l}\text { It is often difficult for parents, caregivers, and } \\
\text { interventionist to teach toileting In this study identifying } \\
\text { items that function as reinforcement, in the independence } \\
\text { of defecating and defecating in the toilet and decreasing } \\
\text { accidents in the toilet }\end{array}$ \\
\hline 4 & $\begin{array}{l}\text { Lotta } \\
\text { Mundhenke,Liselotte } \\
\text { Hermansso } \\
\text { \&Birgittasjo-qvist } \\
\text { Nutterlund }\end{array}$ & $\begin{array}{l}\text { Experiences of } \\
\text { Swedish } \\
\text { children with } \\
\text { disabilities: } \\
\text { activities }\end{array}$ & 2010 & $\begin{array}{l}\text { Scandinavian } \\
\text { Journal of } \\
\text { Occupational } \\
\text { Therapy }\end{array}$ & $\begin{array}{l}33 \text { people } \\
\text { with special } \\
\text { needs with } \\
\text { physical, } \\
\text { intellectual }\end{array}$ & Qualitative & $\begin{array}{l}\text { They (children with special needs) have strategies to } \\
\text { overcome problems as a consequence of their limitations, } \\
\text { both socially and in daily activities. Children receive social } \\
\text { support in daily activities, especially from their family and } \\
\text { close friends. But they feel sad when they cannot }\end{array}$ \\
\hline
\end{tabular}




\begin{tabular}{|c|c|c|c|c|c|c|c|}
\hline No & Author Name & $\begin{array}{l}\text { Article } \\
\text { Title }\end{array}$ & $\begin{array}{c}\text { Year } \\
\text { Published }\end{array}$ & $\begin{array}{l}\text { Journal } \\
\text { Name }\end{array}$ & $\begin{array}{c}\text { Subject } \\
\text { Research }\end{array}$ & $\begin{array}{l}\text { Research } \\
\text { Method }\end{array}$ & Result \\
\hline & & $\begin{array}{lr}\text { and } & \text { social } \\
\text { support in } & \text { in } \\
\text { daily life } & \end{array}$ & & & $\begin{array}{l}\text { and neuro } \\
\text { psychiatric } \\
\text { limitations }\end{array}$ & & $\begin{array}{l}\text { participate in daily activities carried out by their peers who } \\
\text { are in normal conditions. }\end{array}$ \\
\hline 5 & Yadwinder Kaur & $\begin{array}{l}\text { Family } \\
\text { Support } \\
\text { Model for the } \\
\text { Management } \\
\text { of Disabled } \\
\text { Children }\end{array}$ & 2010 & Routledge & $\begin{array}{l}150 \quad \text { parents } \\
\text { who have } \\
\text { children with } \\
\text { special needs }\end{array}$ & Quantitative & $\begin{array}{l}\text { The way parents understand children with limitations } \\
\text { influences parent-child relationships. When ABK care and } \\
\text { management was found to be related to the level of child } \\
\text { dependence and the extent of the child's behavior } \\
\text { problems. As many as } 64 \% \text { of ABK were treated by their } \\
\text { mothers, besides that it was found to be lack of knowledge } \\
\text { of parents, economic problems and lack of resources. ABK } \\
\text { requires extra time for treatment. }\end{array}$ \\
\hline 6 & Paulks., et al & $\begin{array}{l}\text { Using the } \\
\text { International } \\
\text { Classification } \\
\text { of Functioning } \\
\text { Disability and } \\
\text { Health (ICF) } \\
\text { to Describe } \\
\text { Children } \\
\text { Referred to } \\
\text { Special Care } \\
\text { or Pediatric } \\
\text { Dental } \\
\text { Services }\end{array}$ & 2013 & Plos one & $\begin{array}{l}\text { Children with } \\
\text { special needs }\end{array}$ & Quantitative & $\begin{array}{l}42.6 \% \text { of dental caries } \\
44 \% \text { dentofacial anomalies } \\
58 \% \text { of tooth structure disorders } \\
9.2 \% \text { experienced caries and dentofacial anomalies }\end{array}$ \\
\hline 7 & Zachari, savaci & $\begin{array}{l}\text { The impact of } \\
\text { menstruation } \\
\text { in adolescents } \\
\text { with } \\
\text { disabilities } \\
\text { related to } \\
\text { cerebral palsy }\end{array}$ & 2010 & $\begin{array}{l}\text { Arch Dish } \\
\text { Child }\end{array}$ & $\begin{array}{l}\text { Disabled } \\
\text { children of } \\
\text { women aged } \\
12-18 \text { years }\end{array}$ & Quantitative & $\begin{array}{l}59 \text { people }(76 \%) \text { were happy to get the first period } \\
50 \% \text { ask for advice before getting the first period } \\
\text { The severity of disability is closely related to social } \\
\text { weakness due to menstruation }\end{array}$ \\
\hline 8 & $\begin{array}{l}\text { Wilson, } \quad \text { Cumella, } \\
\text { Parmenter, }\end{array}$ & $\begin{array}{l}\text { Penile } \\
\text { hygiene: }\end{array}$ & 2009 & $\begin{array}{l}\text { Journal of } \\
\text { Intellectual }\end{array}$ & $\begin{array}{l}\text { Boys with } \\
\text { intellectual }\end{array}$ & $\begin{array}{l}\text { Quantitative } \\
\text { and }\end{array}$ & $\begin{array}{l}\text { Daily cleaning of the penis by pulling the foreskin is } \\
92.5 \% \text { and } 7.5 \% \text { which cleanses the penis by not pulling }\end{array}$ \\
\hline
\end{tabular}


IJDS 2019; Vol. 6 No. 1, May 2019, pp. 64-72

ISSN: $2355-2158$

DOI:

\begin{tabular}{|c|c|c|c|c|c|c|c|}
\hline No & Author Name & $\begin{array}{c}\text { Article } \\
\text { Title }\end{array}$ & $\begin{array}{c}\text { Year } \\
\text { Published }\end{array}$ & $\begin{array}{c}\text { Journal } \\
\text { Name }\end{array}$ & $\begin{array}{c}\text { Subject } \\
\text { Research }\end{array}$ & $\begin{array}{c}\text { Research } \\
\text { Method }\end{array}$ & Result \\
\hline & Stancliffe,Shutttleworth & $\begin{array}{l}\text { puberty, } \\
\text { paraphimosis } \\
\text { and personal } \\
\text { care } \\
\text { for men and } \\
\text { boys with an } \\
\text { intellectual } \\
\text { disability }\end{array}$ & & $\begin{array}{l}\text { Disability } \\
\text { Research }\end{array}$ & disabilities & Qualitative & $\begin{array}{l}\text { the foreskin and as much as } 60.4 \% \text { do not know to pull the } \\
\text { foreskin when cleaning the penis. In addition data obtained } \\
\text { from abnormalities in children namely phimosis or para } \\
\text { phimosis as a result of not cleaning the penis by pulling } \\
\text { the foreskin }\end{array}$ \\
\hline 9 & $\begin{array}{l}\text { S. R. Cohen, S. D. } \\
\text { Holloway, } \\
\text { Domínguez-Pareto2 } \text { \&. } \\
\text { M. Kuppermann3 }\end{array}$ & $\begin{array}{l}\text { Receiving or } \\
\text { believing in } \\
\text { family } \\
\text { support? } \\
\text { Contributors } \\
\text { to } \\
\text { the life quality } \\
\text { of Latino and } \\
\text { non-Latino } \\
\text { families of } \\
\text { children with } \\
\text { intellectual } \\
\text { disability }\end{array}$ & 2014 & $\begin{array}{l}\text { Journal of } \\
\text { Intellectual } \\
\text { Disability } \\
\text { Research }\end{array}$ & $\begin{array}{l}\text { Mothers who } \\
\text { have } \\
\text { intellectual } \\
\text { disabilities } \\
\text { children aged } \\
2 \text { to } 10 \text { years }\end{array}$ & $\begin{array}{l}\text { Quantitative } \\
\text { (Cross } \\
\text { sectional) }\end{array}$ & $\begin{array}{l}\text { Parenting style is not only influenced by stress, but also } \\
\text { influenced by family functions. One example in a family } \\
\text { having normal children and children with special needs } \\
\text { family functions affect parenting styles differently }\end{array}$ \\
\hline
\end{tabular}

